\title{
Noise Impact of Southgate Phase-2 Construction Project to the Settlement at Perumahan Tanjung Mas, Tanjung Barat
}

\author{
Askarini Sekar Putri ${ }^{1}$ \\ ${ }^{1}$ KSO Sarana, Totalindo Nuansa Cilangkap, Jakarta Timur, 13870, Indonesia \\ e-mail: askarini.sekar@gmail.com
}

\begin{abstract}
Construction activities can increase noise that gives an impact on the people who live nearby. The impact of noise can cause psychological and physiological disorders. The purpose of this research is to analyze the effects of the noise level of the Southgate Phase-2 project for citizen activities at PerumahanTanjung Mas, Tanjung Barat. It is based on regulatory standards in KEPMEN LH no. 48 of 1996, KEPGUB DKI Jakarta no. 551 of 2001, and the LNP standard according to the US Department of Housing and Urban Development. The methods are doing observation and survey by using a questionnaire to find out the project situation and the noise level produced by using a sound level meter measuring instrument. The result shows that people feel discomfort from the noise of the project, especially at night. Most of the noise measurement result exceeds the noise quality standard and its effects up to 50 meters away from the noise source. The point which is about 5 meters away from the noise source is $63.73 \mathrm{~dB}(\mathrm{~A})$ and point which is about 50 meters away from the noise source is $59.89 \mathrm{~dB}(\mathrm{~A})$. Based on the results of the regression equation shows that houses within 120 meters of the project impacted by the noise that exceeds the noise quality standards for the residential area. The most complaints given by people of PerumahanTanjung Mas were feeling discomfort in daily activities (79\%), and sleeping trouble (60\%).
\end{abstract}

Keywords: Noise Disturbance; Citizen Comfort; Construction Project

\section{INTRODUCTION}

Based on the Rancangan Pembangunan Jangka Menengah Daerah DKI Jakarta 2017-2020, there are plans to provide an apartment for 14,564 units. This is the government's effort to meet the occupancy backlog that occurred in 2016 as many as 302,319 units. Several projects in Jakarta flats built adjacent to settlements that impacts to the surrounding environment, such as noisy. Noise is an unwanted sound from activity at a certain level and time that can cause disturbance to human health and environmental comfort. Noise pollution in urban areas is the most serious type of environmental pollution after air and water pollution (Concha, 2004). The results of Dewanty and Sudarmadji's research (2016) say that noise pollution in urban areas is generally generated from road traffic, construction and commercial activities of industries, airports, and residential areas. Noise arising during the construction phase are usually sourced from heavy equipment and machinery is used, it could lead to increased noise and disturbing the surrounding area. Impact mitigation can be carried out at three handling points, namely at the source, at the propogation path, and at the point of receiving the impact (Beanlands and Duinker, 1983).

Perumahan Tanjung Mas at Tanjung Barat is adjacent to a variety of noise sources, namely from highways, train stations, and construction projects. This can cause noise intensity in the housing to be very large. According to Djalante (2010), people who are exposed to noise can tolerate the noise depending on the activities that they are doing, the amount of noise intensity, and the duration of exposure to the noise intensity. People who are exposed to noise for a long time and to a certain degree can disrupt the psychological condition and health of the 
community (Bell et al, 2001). Noise can cause psychological disorders, communication disorders, and physiological disorders. Psychological disorders in the form of discomfort in activities, easy emotions, loss of concentration, and so on (Preiser, 1988). Communication disorders such as difficulty hearing the conversations of others when communicating. Physiological disorders such as headache or dizziness, insomnia, muscle tension, and so on (Plessis, 2002). Noise that exceeds the upper threshold (threshold of pain) can lead to temporary deafness and permanent deafness.

This research refers to the Keputusan Menteri Lingkungan Hidup (KEPMENLH) no. KEP-48/MENLH/ 11/1996 and Keputusan Gubernur (KEPGUB) DKI Jakarta no. 5512001 standard noise level based housing and residential areas which is set at $55 \mathrm{~dB}$ (A). LNP standard according to the US Department of Housing and Urban Development noise pollution index (LNP) that can be accepted by the public is $58-74 \mathrm{~dB}$. The purpose of this study, which is to analyze the effect of the noise level of construction projects based on the KEPMENLH no. 48 of 1996, KEPGUB DKI Jakarta No. 551 of 2001, and $\mathrm{L}_{\mathrm{NP}}$ standards according to the US Department of Housing and Urban Development in the activities of residents in Perumahan Tanjung Mas. Traffic regulation to reduce traffic volume of passing vehicles. This can be done by carrying out traffic engineering, construction of ring roads to reduce the burden on the urban road network, and others (Departement of Transport, 1988).

In a previous study, entitled Tingkat Kebisingan di Kawasan Permukiman Sekitar PLTD Muara Teweh discusses the influence of noise on the activities of people in settlements bordering the PLTD Muara Teweh (Hasanah and
Maharso, 2016). But in this study discusses the effect of noise on the activities of people in settlements bordering the building construction project. This research can provide information to the government, service providers, and construction service users about the effect of construction project noise on the comfort of citizen's activities in PerumahanTanjung Mas.

\section{METHODS}

This research was conducted at Perumahan Tanjung Mas adjacent to the SGP2 Project site at Tanjung Barat [Figure 1]. The method used in this study are observation methods and survey methods. The observation method used is measuring noise on five points at Perumahan Tanjung Mas. The five points have different distances to the noise source (the barrier of SGP2 Project), the distance of the first point to the noise source is 150 meters away, the second point 50 meters away, the third point 5 meters away, the fourth point 20 meters away, and the fifth point 100 meters away. This noise measurement used a tool a sound level meter (SLM) as a noise measurement tool, a tripod as a tool to maintain the stability of the SLM, and a stopwatch. SLM works by sending sound waves through the microphone and then converted into electrical signals which arise on the display as a result of noise measurement (dB). This measurement refers to the method regulated in KEPMENLH no. 48 of 1996 , by using a simple measurement method with regular SLM to measure the sound pressure level $\mathrm{dB}$ (A) for 10 minutes for each measurement with readings performed every 5 seconds. The time measurements were carried out for 24 hours ( $\left.\mathrm{L}_{S M}\right)$, daytime levels for 16 hours (Ls) at 6:00 a.m. to 22:00 and evenings for 8 hours $\left(\mathrm{L}_{\mathrm{M}}\right)$ at the time of 22:00 to 6:00. 
Each measurement should represent a certain time interval, at least four-time measurements during the day and at least three-time measurements during the night. In this study, carried out at the time:

- L1 is taken at 08:00 representing 06:00 - 09:00

- L2 is taken at 10:00 representing 09:00 - 12:00

- L3 is taken at 14:00 representing 13:00 - 15:00

- L4 is taken at 16:00 representing 15:00 - 18:00

- L5 is taken at 18:30 representing $18: 30-19: 30$

- L6 is taken at 20:00 representing 20:00 - 21:00

- L7 is taken at 21:00 representing 21:00 - 22:00

In this study, noise measurements were carried out only until 22:00 due to SGP2 Project activities which ended at 22.00. Measurement noise is divided into two days, weekdays (Monday-Friday) and weekend (Saturday-Sunday).

The survey method in this study is using a questionnaire that contains questions about the responses from the residents about the noise from the SGP2 Project. The sampling method using a Purposive Random Sampling, which is a sampling technique that picks the sample randomly without considering the stratum in the population, but the determination of the sample is based on certain considerations. In this study, the area was determined based on housing blocks affected by noise from the SGP2 Project, which is Block A and Block B. Block A consisted of 80 houses and Block B consisted of 36 houses, so the number of the population is 116 houses. The samples in this study using the Slovin formula. The formula is as follows:

$$
n=\frac{N}{N\left(e^{2}\right)+1} \ldots \ldots . . .(\text { Equation } 1)
$$

Information:

$\mathrm{n}=$ Sample

$\mathrm{N}=$ Population

$\mathrm{d}=$ Margin of error or inaccuracy due to sampling that can be tolerated. (15\%).

The results of the samples using Equation 1, obtained a total sample of 32.13 samples and rounded to 35 samples. Measurements using this questionnaire are conducted every Saturday from 08:00 - 11:00.

For data analysis techniques in this study, using correlation tests, and regression tests. The function of the correlation test is to determine the strength of the relationship between variables, in this study used a Bivariate / Pearson Correlation correlation type. The regression test used in this study is a simple linear regression, that has a function to formulate the relationship between the dependent variable models with one independent variable. Data analysis was using Microsoft Excel and Statistical Package of Social Sciences (SPSS) applications. To process the result of noise measurement was used the Microsoft Excel application, meanwhile for correlation and regression test was used the SPSS application.

The first stage in collecting data was distributed the questionnaires to respondents. Second, was measured noise at a predetermined location based on the method according to KEPMENLH no. 48 of 1996. Third, was processed noise measurement data to get the value of $\mathrm{LSM}_{S \mathrm{M}}$ with the following formula [2]:

$$
\begin{aligned}
\mathrm{L}_{\mathrm{SM}}= & 10 \log 1 / 24\left[16.10^{0.1 \cdot \mathrm{LS}}+\ldots+\right. \\
& \left.8.10^{0.1(\mathrm{LM}+5)}\right] \ldots \ldots \ldots .(\text { Equation } 2)
\end{aligned}
$$

Information:

$\mathrm{L}_{S M}=\mathrm{L}_{\mathrm{EQ}}$ during the night and the day $(\mathrm{dB}(\mathrm{A}))$

$\mathrm{L}_{\mathrm{EQ}}=$ Equivalent Continuous Noise Level is the value of the noise level of the noise fluctuations over time, 
which is equivalent to the noise level of the noise steadily at the same time interval.

Where:

$$
\begin{aligned}
\mathrm{L}_{\mathrm{S}}= & \mathrm{L}_{\mathrm{EQ}} \text { during the day }(\mathrm{dB}(\mathrm{A})) \\
= & 10 \log 1 / 16\left[\mathrm{~T} 1.10^{0.1 . \mathrm{L} 1}+\ldots+\right. \\
& \left.\mathrm{T} 4.10^{0.1 . \mathrm{L} 4}\right] \ldots \ldots \ldots . .(\text { Equation } 3) \\
\mathrm{L}_{\mathrm{M}}= & \mathrm{L}_{\mathrm{EQ}} \text { during the night }(\mathrm{dB}(\mathrm{A})) \\
& 10 \log 1 / 8\left[\mathrm{~T} 5.10^{0.1 . \mathrm{L} 5}+\ldots+\right. \\
& \left.\mathrm{T} 7.10^{0.1 . \mathrm{L} 7}\right] \ldots \ldots \ldots . .(\text { Equation } 4)
\end{aligned}
$$

to calculate L1-7 is as follows:

$$
\begin{aligned}
\mathrm{L}_{1-7}= & \mathrm{L}_{\mathrm{EQ}}(10 \text { minutes }(\mathrm{dB}(\mathrm{A})) \\
= & 10 \log 1 / 10 \quad\left[10^{0.1 \mathrm{LI}}+\ldots+\right. \\
& \left.10^{0.1 \mathrm{Lxii}}\right] \times 1 \ldots \ldots \ldots \ldots(\text { Equation } 5) \\
\mathrm{L}_{\mathrm{I}-\mathrm{xii}}= & \mathrm{L}_{\mathrm{EQ}}(1 \text { minute })(\mathrm{dB}(\mathrm{A})) \\
= & 10 \log 1 / 60 \quad\left[10^{0.1 \mathrm{~L} 1}+\ldots+\right. \\
& \left.10^{0.1 \mathrm{~L} 10}\right] \times 5 \ldots \ldots \ldots(\text { Equation } 6)
\end{aligned}
$$

After obtaining the value of $\mathrm{LSM}_{\mathrm{SM}}$ on weekdays and weekends, the results are processed by the SPPS application to find out the relationship between variables using regression and correlation tests (Hikmatullah and Putra, (n.d.). The noise intensity as the dependent variable, and the point distance to the noise source as the independent variable. Then test the descriptive data for the known value of a standard deviation.

Next, calculate the noise pollution index (LNP) according to the US Department of Housing and Urban Development. The formula of LNP developed by Robinson (1995) is as follows:

$\mathrm{L}_{\mathrm{NP}}=\mathrm{L}_{\mathrm{EQ}}+2.56 \sigma$ (Equation 7)

Where:

$\sigma=$ standard deviation (statistically determined from all data that appears).

Then, analyse the results of the questionnaire and the results of calculations from noise measurement data. The results of the calculation of noise measurements are analysed with noise quality standard values based on KEPMENLH regulation no. 48 of 1996,
KEPGUB DKI Jakarta no. 551 of 2001, and LNP standards according to the US Department of Housing and Urban Development (Table 1) (Table 2). The last, make conclusions and suggestions from the whole study.

\section{RESULTS AND DISCUSSION}

Noise calculation results are divided into two methods, based on KEPMENLH no. 48 of 1996 and the calculation of the LNP (Noise Pollution Index). First, based on the calculation method according to KEPMENLH no. 48 of 1996,3 points exceeded the noise quality standard, there was the third point which is 5 meters from the noise source, the fourth point which is 20 meters from the noise source, and the second point which is 50 meters from the noise source. The intensity of noise on weekdays can be seen in Figure 2 and on holidays can be seen in Figure 3. Both figures show the relation between noise intensity and the point distance to the noise source. If the distance from the point to the noise source was further, the noise intensity at that point was getting smaller, and vice versa. Figure 4 shows the measurement result of the noise intensity on weekdays, and Figure 5 for measurement result on weekends. Based on both figures, the third point, the fourth point, and the fifth point, at each measurement time mostly exceed the noise quality standard.

In Figure 4, the relation between noise intensity and time of noise measurement on weekdays has an irregular pattern. Because on weekdays the casting work started at 16:00 - 22:00, so at night it didn't show a decrease in noise intensity. Based on Figure 4, the relation between noise intensity and time of measurement on weekends also has an irregular pattern, but the noise intensity decreased at all points at 16:00 - 19:00. Because the project activities have stopped at 18:00 on weekends, so most of the noise 
intensity at each point was below the noise quality standard after 18:00. Noise at that time was only the sound of vehicles passing around the measurement location. So the conclusion is, the noise intensity with the time of measurement noise didn't indicate a relationship. Furthermore, based on the LNP calculation method on weekends at the third point has a value that exceeds the tolerance limit of the community (Table 2) of $74.88 \mathrm{~dB}$ as you can see in Figure 6. On weekdays the LNP value at each point is still within the limits of community tolerance. So the conclusion is, most of the residents can tolerate the noise due to the SGP2 Project, and only the residents who live nearby the third point can't tolerate the noise. However, these results do not correspond with the results of the questionnaire.

The results of respondent's responses based on the questionnaire showed that all respondents felt that the sound generated by the SGP2 Project was noisy, as many as $77 \%$ of respondents experienced psychological disorders that were disturbed or uncomfortable in their activities, as many as $60 \%$ of respondents experienced physiological disorders in the form of insomnia, and as many as $77 \%$ of respondents wanted the noise around their home decrease. These results are consistent with the results of the study "Tingkat Kebisingan di Kawasan Permukiman Sekitar PLTD Muara Teweh" i.e respondents exposed to noise $\leq 70 \mathrm{~dB}(\mathrm{~A})$ were mostly uncomfortable and had difficulty sleeping (Hasanah and Maharso, 2016). In this study, there are other findings data that most of the respondents complained about the dust was increasing at their houses, so that some respondents were suffering from diseases generated by dust, including ISPA, cough, and DHF. People exposed to cement dust can get cough, narrowing of the respiratory tract, and other respiratory diseases (Croome and Mashrae, 1977). Others complained about the styrofoam material was flying into the roof of the respondent's house, which caused the rainwater to clog, and complained about vibration from project activities that caused cracks in the resident's houses at the finishing part.

The result of the correlation test showed a strong relationship between the noise intensity variable (dependent variable) with the distance variable (independent variable). The relation has a nondirectional relationship, it means the further the distance from the point to the noise source, the less noise intensity at that location. Based on the regression test results, obtained the following equation:

$\hat{y}=63.346-0.069 x \ldots \ldots . .($ Equation 8$)$

Information:

$\hat{y}=$ Noise intensity $(\mathrm{dB}(\mathrm{A}))$

$\mathrm{x}=$ Distance $(\mathrm{m})$

The calculating result based on Equation 8, shows that houses within 120 meters of the barrier of the SGP2 Project exposed to noise that exceeds the noise quality standard for residential areas according to KEPMENLH no. 48 of 1996 that is $55 \mathrm{~dB}(\mathrm{~A})$, you can see the result of this equation in Figure 7. It means, due to the noise from the SGP2 Project, about $30 \%$ of the Perumahan Tanjung Mas area was exposed to noise more than $55 \mathrm{~dB}(\mathrm{~A})$.

Based on the discussion, the noise generated from the SGP2 Project disturbed the comfort of the residents and made them difficult to sleep at night because the project activities were still working until 22:00. The noise also impacts up to a distance of 120 meters from the SGP2 Project.There are several ways to reduce noise, such as place the activities that cause noise at the busy hour, and replace the barrier material with a material that can reduce noise up 
to $15 \mathrm{~dB}(\mathrm{~A})$, such as a $9.5 \mathrm{~mm}$ gypsum plasterboard. The people who live nearby the project site, can reduce the noise by plant grass and trees in their yard. When the surface of the earth covered with soil, grass, or tree, it will be quite significant to absorb the sound that propagates, so the sound at that point will get weaker (Mediastika, 2005). Shade plants such as the Angsana and Glodogan trees are used to absorb pollutants chemically and as a noise absorber. It also can reduce the cost of investment and as a green open space (Sharp and Jenning, 1988).

\section{CONCLUSION}

The impact of SGP2 Project construction is the noise that exceeds the quality standard according to KEPMENLH no. 48 of 1996 and KEPGUB DKI Jakarta no. 551 in 2001, which is $55 \mathrm{~dB}$ (A). About $30 \%$ of the total PerumahanTanjung Mas area exposed to the noise of more than $55 \mathrm{~dB}(\mathrm{~A})$. Based on the results of the questionnaire, it affects the activities of residents, most respondents feel disturbed or uncomfortable and have trouble sleeping. The relevant regulation for the SGP2 Project about noise quality standards is KEPMENLH no. 48 of 1996 and KEPGUB DKI Jakarta no. 551 of 2001.

This study can provide information to the government, service users, and construction service providers about the effect of noise caused at the construction stage for the surrounding settlements. In this study, the authors have limited time in collecting data. For further research, it is recommended to study other variables that affect noise intensity and discuss other impacts of construction project activities, such as air quality.

\section{REFERENCES}

Beanlands, G. E. and Duinker P. N. (1983). An ecological framework for environmental impact assessment in Canada. Dalhousie University and Federal Enviromental Assessment Review Office, Hull, P. Q.

Bell, P. A., Greene, T. C., Fisher, J. D., and Baum, A. (2001). Enviromental Psychology. New York: Harcourt College Publisher.

Concha-Barrientos, M., CampbellLendrum, D., \& Steenland, K. (2004). Assessing the burden of disease from work-related hearing impairment at national and local levels. World Health Organization Protection of the Human Environment, Environmental Burden of Disease Series, No. 9

Croome, D. J., and Mashrae. (1977). Noise Buildings and People. Oxford: Pergamon Press.

Departement of Transport. (1988). Calculation of Road Traffic Noise Levels. London: HMSO.

Dewanty, R. A., \& Sudarmaji, S. (2016). Impact Analysis of Noise Intensity with Hearing Loss on Laundry Worker. Jurnal Kesehatan Lingkungan, 8(2), 229-237.

Djalante, S. (2010). Analisis Tingkat Kebisingan Di Jalan Raya Yang Menggunakan Alat Pemberi Isyarat Lalu Lintas (APIL) (Studi Kasus: Simpang Ade Swalayan). SMARTek, 8(4).

Pemerintah Daerah DKI Jakarta. 2001. Keputusan Gubernur Provinsi DKI Jakarta Nomor 551 Tahun 2001 tentang Penetapan Baku Mutu Udara Ambien dan Baku Tingkat Kebisingan di Propinsi DKI Jakarta. Jakarta 
Hasanah, U., As, Z. A., \& Maharso, M. (2016). Tingkat Kebisingan Di Kawasan Permukiman Sekitar PLTD Muara Teweh. JURNAL KESEHATAN LINGKUNGAN: Jurnal dan Aplikasi Teknik Kesehatan Lingkungan, 13(1), 328-336.

Hikmatullah, F. R. \& Putra, A. S. (n.d.). Penentuan Tingkat Kebisingan Lingkungan Menggunakan Alat Sound Level Meter. Skripsi. Bogor: Departemen Teknik Sipil dan Lingkungan, Institit Pertanian Bogor.

Keputusan Menteri Negara Lingkungan Hidup No. 48 Tahun 1996 tentang Baku Tingkat Kebisingan. Jakarta: Kementerian Negara Lingkungan Hidup.
Mediastika, C. E. (2005). Akustika Bangunan. Jakarta: Erlangga.

Pemerintah Daerah DKI Jakarta. 2018. Peraturan Daerah (PERDA) Provinsi Daerah Khusus Ibukota Jakarta Nomor 1 Tahun 2018 tentang Rencana Pembangunan Jangka Menengah Daerah Provinsi DKI Jakarta 2017-2022. Jakarta.

Plessis, C. D. (2002). Agenda 21 for sustainable construction in developing countries. CSIR Report BOU E, 204, 2-5.

Preiser, R. W. (1988). Post Occupancy Evaluation. Van Nostrand Reinhold Company.

Sharp, C. and Jenning, T. (1976). Transport and the Environment. Leicester University Press, Leicester. 
Applied Research on Civil Engineering and Environment (ARCEE) VOL. 03 NO. 01, August 2021

\section{Appendix}

Table 1. Quality Standard of Noise Level at Housing and Residential

\begin{tabular}{clc}
\hline No. & \multicolumn{1}{c}{ Quality Standard } & dB (A) \\
\hline 1 & $\begin{array}{l}\text { Keputusan Menteri Lingkungan Hidup (KEPMENLH) } \\
\text { no. KEP-48/MENLH/ 11/1996 }\end{array}$ & 55 \\
\hline 2 & $\begin{array}{l}\text { Keputusan Gubernur (KEPGUB) DKI Jakarta no. 551 } \\
\text { 2001 }\end{array}$ & 55 \\
\hline 3 & $\begin{array}{l}\text { Standard of LNP according to US Department of } \\
\text { Housing and Urban Development }\end{array}$ & $58-74$ \\
\hline
\end{tabular}

Table 2. Standard of $\mathrm{L}_{\mathrm{NP}}$ according to US Department of Housing and Urban Development

\begin{tabular}{ccc}
\hline No. & LNP & Community Acceptance Criteria \\
\hline 1 & $<58 \mathrm{~dB}$ & Acceptable \\
\hline 2 & $58 \mathrm{~dB} \leq \mathrm{L}_{\mathrm{NP}} \leq 74 \mathrm{~dB}$ & Still acceptable \\
\hline 3 & $74 \mathrm{~dB} \leq \mathrm{L}_{\mathrm{NP}} \leq 88 \mathrm{~dB}$ & Generally unacceptable \\
\hline 4 & $>88 \mathrm{~dB}$ & Very unacceptable \\
\hline
\end{tabular}




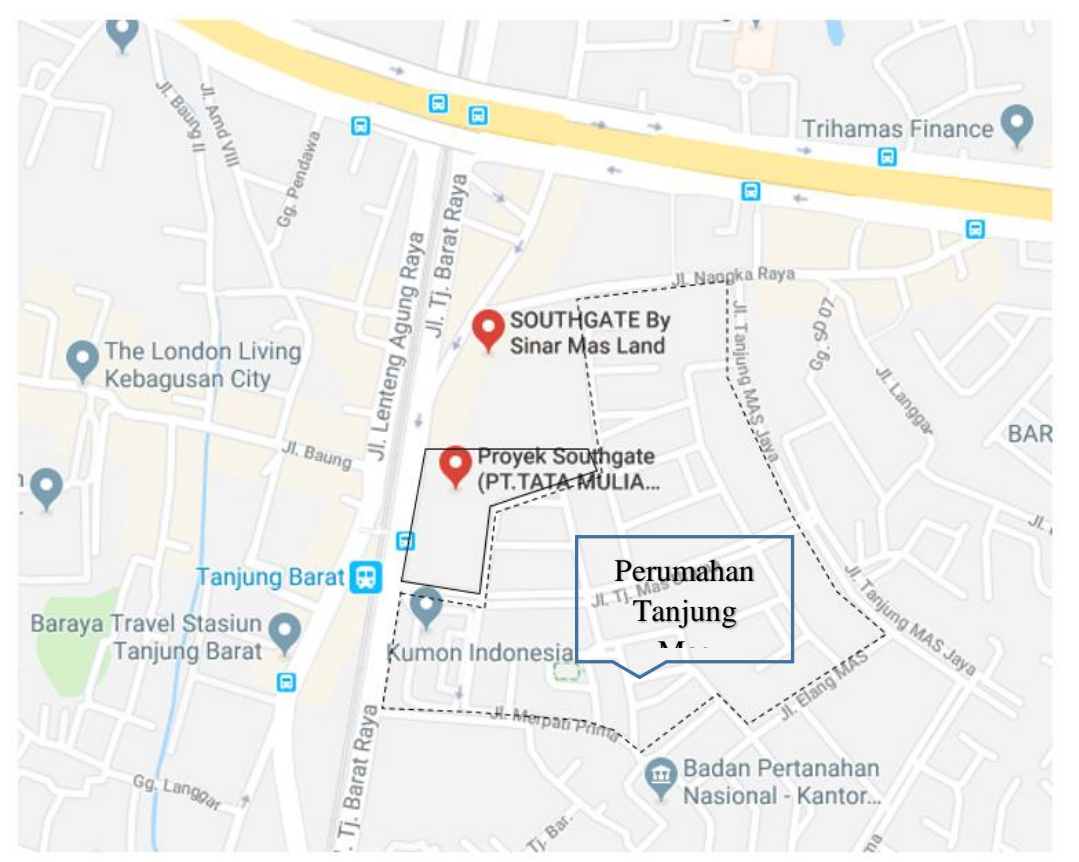

Figure 1. Location of Perumahan Tanjung Mas Tanjung Barat and SGP2 Project

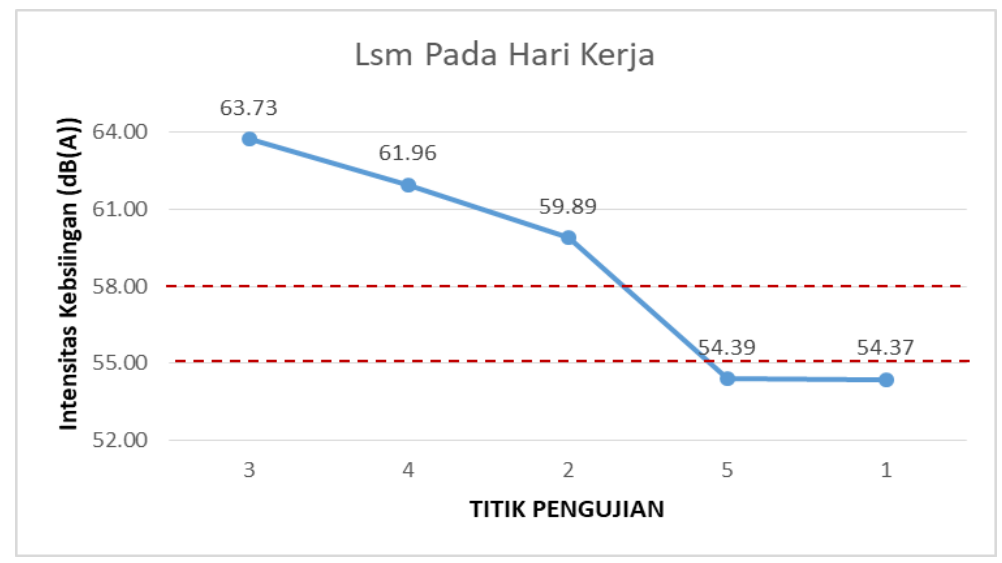

Figure 2. Chart of Lsm on Weekdays

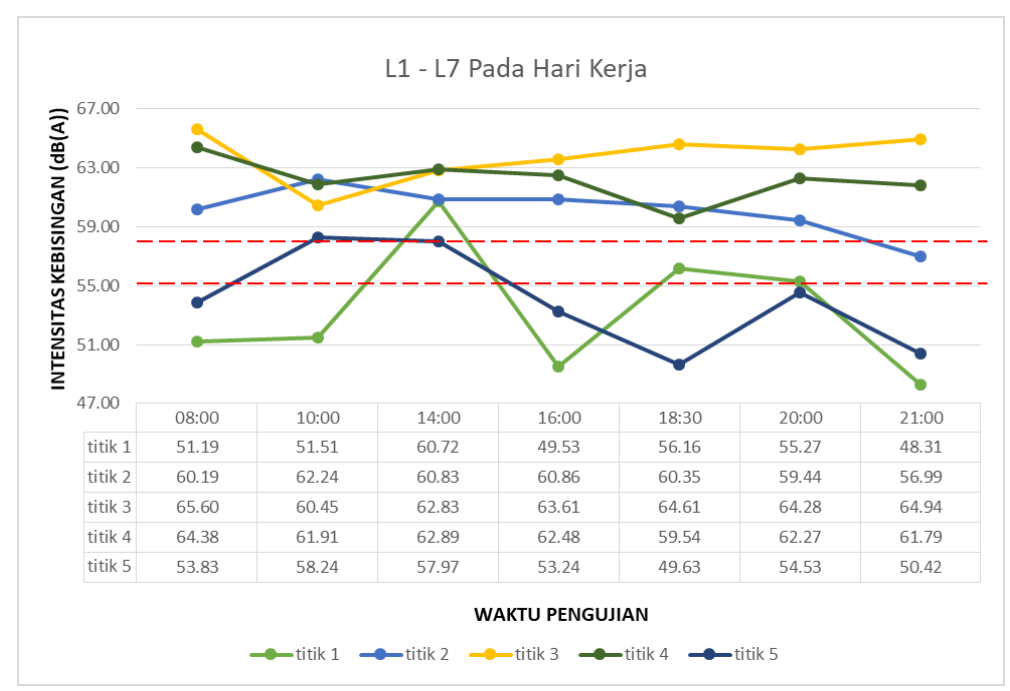

Figure 3. Chart of L1-L7 on Weekdays 


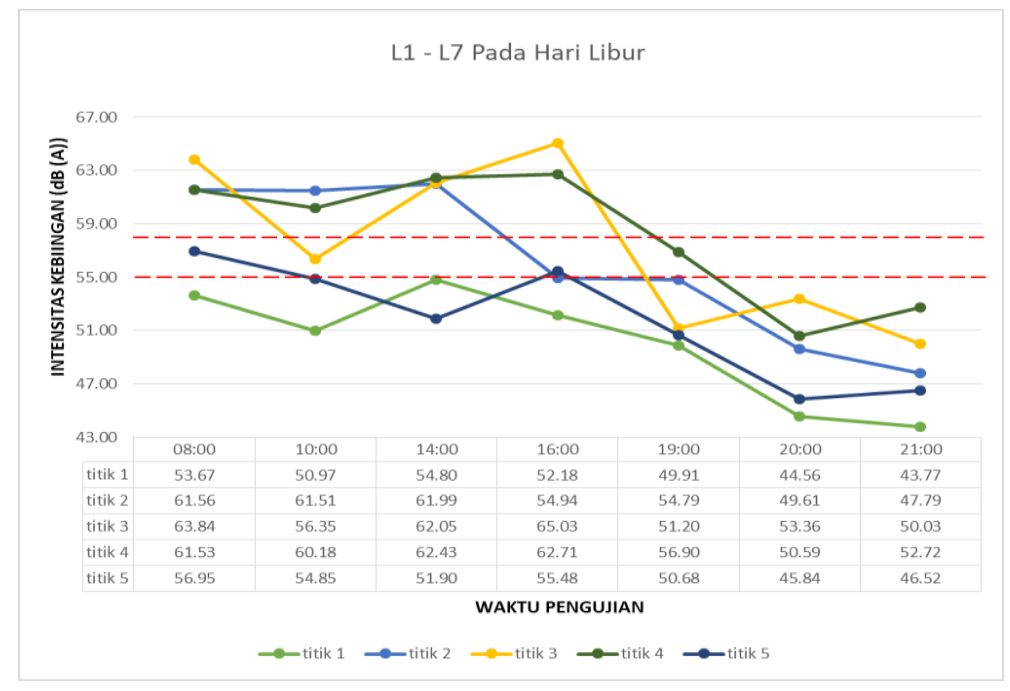

Figure 4. Chart of L1-L7 on Weekends

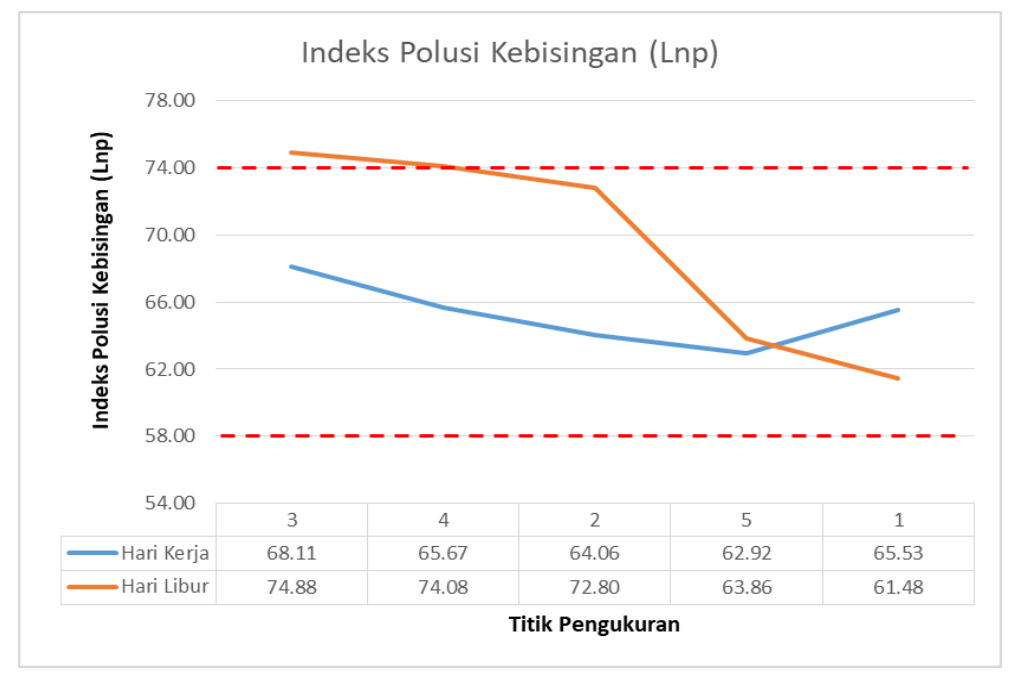

Figure 5. Chart of Lnp

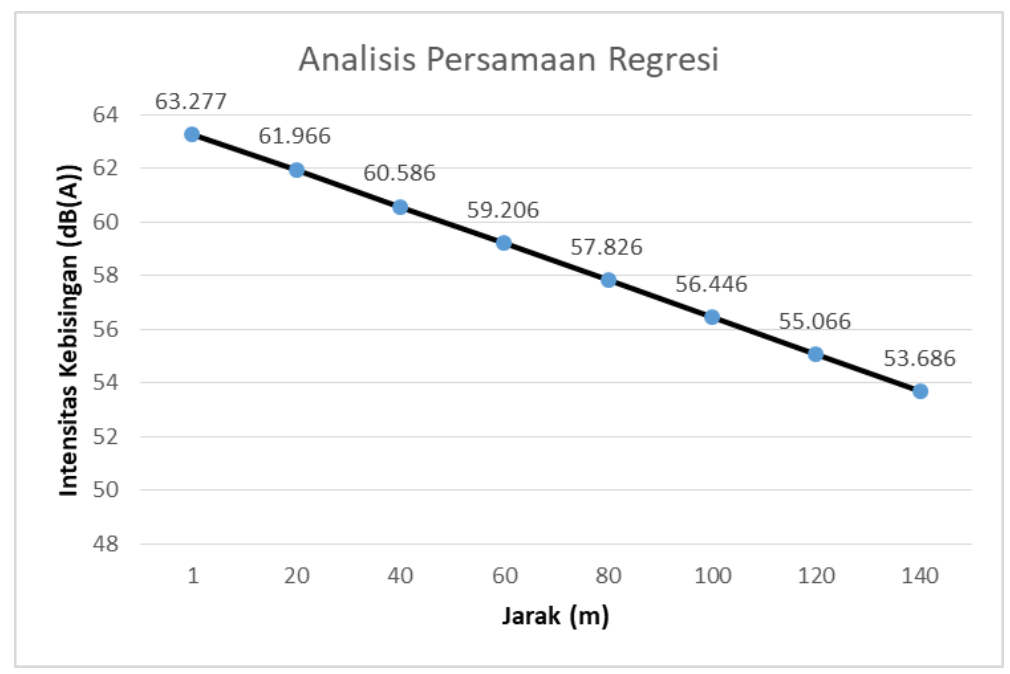

Figure 6. Chart of The Result of The Regression Equation 